\title{
Physico-chemical Properties of Different Carbonate Rocks: Are They Highly Enough to Control Lime Reactivity?
}

\author{
Ioannis Baziotis (Corresponding author) \\ School of Mining and Metallurgical Engineering, Department of Geological Sciences \\ National Technical University of Athens \\ Heroon Polytechniou 9 Street, 15773, Zografou, Athens, Greece \\ Tel: 30-6945-011-320Ｅ-mail: baziotis@metal.ntua.gr
}

George Leontakianakos

School of Chemical Engineering, Laboratory of Inorganic and Analytical Chemistry

National Technical University of Athens, Heroon Polytechniou 9 Street

15773, Zografou, Athens, Greece

E-mail: gleontakianakos@yahoo.gr

\begin{abstract}
Alexander Proyer
Institute of Earth Sciences, Department of Mineralogy and Petrology

Karl-Franzens University, Universitätsplatz 2/II, 8010, Graz, Austria

E-mail: alexander.proyer@uni-graz.at
\end{abstract}

Heesoo Lee

School of Materials Science and Engineering, Pusan National University, Busan, Korea

E-mail: heesoo@pusan.ac.kr

Stamatios Tsimas

School of Chemical Engineering, Laboratory of Inorganic and Analytical Chemistry

National Technical University of Athens, Heroon Polytechniou 9 Street

15773, Zografou, Athens, Greece

Received: January 5, 2011 Accepted: January 26, 2011 doi:10.5539/ijc.v3n2p187

Sincere thanks are due to Onassis Foundation for the financial support to G. Leontakianakos. (Sponsoring information)

\begin{abstract}
We have examined 5 different carbonate rocks in order to study their behavior during calcination at different temperatures $\left(900,1050\right.$ and $1200^{\circ} \mathrm{C}$ for $30 \mathrm{~min}$ ) and hydration properties of quick limes and the final interconnection of the primary material with the reactivity of the slaked lime. Quick limes calcined at $900^{\circ} \mathrm{C}$ show the lower reactivity values. This could be related to the low calcination temperature or to the short calcination time of $30 \mathrm{~min}$ which was insufficient to produce enough lime. The samples calcined at temperatures of $1200^{\circ} \mathrm{C}$ are less reactive compared to those calcined at $1050^{\circ} \mathrm{C}$, indicated by parameters such as the $(\mathrm{CaO}+\mathrm{MgO})_{\text {Lime }}$, the time required to reach the temperature maximum and the reactivity rate. This, probably could be due to annealing effects such as crystal coarsening and reduction of porosity at relatively high temperatures.
\end{abstract}


Keywords: Quick lime, Calcination temperature, Reactivity, Hydration

\section{Introduction}

Limestones and their varieties represent the most frequently used rocks in industry and range amongst the thirty most important raw materials. Carbonate rocks mainly consist of carbonate minerals of calcium and magnesium (calcite, dolomite, magnesite)(e.g. Oates 1998). One of the most important industrial applications of limestones is the production of quick lime by calcination due to the reaction:

$$
\mathrm{CaCO}_{3}(\mathrm{~s}) \rightarrow \mathrm{CaO}(\mathrm{s})+\mathrm{CO}_{2}(\mathrm{~g}) .
$$

This reaction is endothermic, proceeds at very high temperatures $\left(>900^{\circ} \mathrm{C}\right)$ and in closed systems is highly influenced by the partial pressure of the gas phase $\left(\mathrm{PCO}_{2}\right)$. The theoretical dissociation temperature of calcite is around $900^{\circ} \mathrm{C}$ whereas that of magnesite ranges from 400 to $550^{\circ} \mathrm{C}$ [e.g. Boynton 1980, Schwarzkopf 1994, Moffat \& Walmsley 2004). Thus, the temperature required for the calcination process of limestone is not constant and depends on various factors like $\mathrm{CaCO}_{3} / \mathrm{MgCO}_{3}$ ratio or differences of grain size.

Another important process is the slaked lime production through the exothermic reaction $\mathrm{CaO}(\mathrm{s})+$ $\mathrm{H}_{2} \mathrm{O}(\mathrm{l}) \rightarrow \mathrm{Ca}(\mathrm{OH})_{2}$. In multicomponent systems, the $\mathrm{MgO}$ content could also react with water to earlier form $\mathrm{Mg}(\mathrm{OH})_{2}$. Both reactions increase the temperature of the added water, which influences reactivity. So, it is important to test the influence of $\mathrm{MgO}$ in such systems. According to various authors, reactivity of quick lime depends on the presence of admixtures in the used limestones; in particular admixtures like $\mathrm{MgO}$ lower the reactivity (Potgieter et al. 2003). As a consequence, the higher the amount of $\mathrm{MgO}$, the lower the reactivity of quick lime, which is expressed in a reduction of the maximum hydration temperature and an increase of hydration time. Another factor that influences the hydration process is the initial temperature of the added water (Boynton 1980). A higher initial temperature of the water used for hydration of the quick lime increases the rate of the hydration reaction due to faster dissolution of the $\mathrm{CaO}$ particles.

The aim of this paper is to analyze the physicochemical properties of the studied carbonate rocks and to test their influence on the hydraulic behavior of quick lime. Additionally, three datasets were obtained, one for each of the three different calcination temperatures (at 900,1050 and $1200^{\circ} \mathrm{C}$ ), regarding reactivity changes of hydrated (slaked) limes. Due to this we attempt to relate the calcination behavior of the original carbonate rocks with the reactivity of the resulted quick-limes.

\section{Experimental work-Analytical methods}

Five samples (K1, A2, T3, T4, T5) of limestones from different quarries in Greece were collected for this study. Limestone particles were reacted in a pre-heated oven at three different temperatures $\left(900,1050\right.$ and $\left.1200^{\circ} \mathrm{C}\right)$ for $30 \mathrm{~min}$ in order to produce quick lime. The tests were done by heating a $200 \mathrm{~g}$ sample of a specific particle size $(1.6-2 \mathrm{~cm})$ at the required temperature. The chosen particle size was arbitrarily used as a constant variable in order to confine the multiplicity of the whole system. Additionally we should keep in our mind that the smaller particle size induces higher values of conversion rate (Oates 1998). Subsequently, following the European standard procedure (NF EN 549-2, 2002), a lime/water 1/4 ratio was used; thus $25 \mathrm{gr}$ of the produced lime were hydrated by adding $100 \mathrm{gr}$ distilled water having a room temperature $\left(\sim 20^{\circ} \mathrm{C}\right)$ to produce $\mathrm{Ca}(\mathrm{OH})_{2}$ through the reaction $\mathrm{CaO}(\mathrm{s})+\mathrm{H}_{2} \mathrm{O}(\mathrm{l}) \rightarrow \mathrm{Ca}(\mathrm{OH})_{2}$. This reaction is highly exothermic, increasing the temperature of the added water. We should keep in our mind that the hydration experiment occurs under adiabatic conditions, continuous stirring and constant monitoring of the temperature variations. We measured the temperature difference in the water until a maximum value was reached; this value represents the reactivity of the produced slaked lime. Additionally, differential thermal analyses (TGA/SDTA) were applied on primary carbonate material and $\mathrm{Ca}(\mathrm{OH})_{2}$ powders in order to estimate the $\mathrm{CO}_{2}$ content and thermal decomposition of hydroxides. The experiments were performed using a 851e Thermogravimetric Analyzer of METTLER TOLEDO at the Laboratory of Inorganic and Analytical Chemistry, School of Chemical Engineering, National Technical University of Athens. The air gas was nitrogen with $50 \mathrm{~cm}^{3} / \mathrm{min}$ flow. The study process begins at $25^{\circ} \mathrm{C}$ with a constant rate $20^{\circ} \mathrm{C} / \mathrm{min}$ until the maximum temperature of $1000^{\circ} \mathrm{C}$.

Chemical composition of each limestone was carried out using atomic absorption spectroscopy (AAS) method. We used a Perkin Elmer 3300 spectrometer at the Department of Chemical Engineering, National Technical University of Athens. The mineral chemical analysis of limestone and lime was performed using a JEOL JSM-5600 scanning electron microscope (SEM) at the Institute of Geology and Mineral exploration. The operating conditions were: $15 \mathrm{KV}, 5 \mathrm{nA}$, data acquisition time $100 \mathrm{~s}$ and beam diameter 4-8 $\mu \mathrm{m}$. All samples were measured with energy dispersive system (EDS).

Detailed petrographic investigation was carried out on prepared thin sections in order to elucidate the mineral 
relationships, textures, relative grain size and shape of the initial material. Raman micro-spectroscopy and X-ray diffraction methods were applied in order to identify the mineral phases in the studied rocks and their products. Analyses were performed using a Renishaw confocal RM1000B Raman Microprobe and a Siemens D-500 with a graphite crystal monochromator. Raman spectra were excited at room temperature using the $632.817 \mathrm{~nm}$ line of the He-Ne laser. The spot at the surface of the sample is about $5 \mu \mathrm{m}$ using a $100 \times$ objective with laser power $<5$ $\mathrm{mW}$. The diffraction interval was between 20 and $50^{\circ} 2 \theta$ with a narrow 0.020 step. Raman micro-spectrometer is based at the Department of Geosciences of the National Technical University of Athens and the X-ray diffractometer at the Institute of Geology and Mineral exploration. The modal percentage of each mineral (calcite, dolomite, quartz, albite) in 5 carbonates was calculated applying a semi-quantitative XRD method. Confirmation of the XRD results was established using Raman micro-spectroscopy. Representative whole-rock carbonate compositions and mineral mode results are summarized in Table 1.

Finally the specific weight and porosity are measured applying RILEM standard test methods (Rilem 1980). Specific weight and porosity measurements can be found elsewhere in detail (Koukis \& Sabatakakis 2002) and is no longer discussed here. The specific weight and porosity are determined applying the following equations respectively:

$\mathrm{D}=\mathrm{Ms} /($ Msat-Msub) and

$\mathrm{n}=\mathrm{Vu} / \mathrm{Vt} * 100$,

where $\mathrm{Vu}=(\mathrm{Msat}-\mathrm{Ms}) / \rho \mathrm{w}$ and $\mathrm{Vt}=($ Msat $-\mathrm{Msub}) / \rho \mathrm{w}$.

Msat: mass of wet sample

Ms: mass of dry sample

Msub: mass of immerse sample

$\rho w$ is the density of water

Measurements of specific weight and porosity of different carbonate rocks are summarized in Table 2.

\section{Results}

\subsection{Petrography and chemistry relations}

Five samples of carbonate rocks were examined with transmitted light microscopy and scanning electron microscopy (SEM) for textural relations of the constituent minerals which are: Calcite + Dolomite \pm Quartz \pm Albite. Albite and quartz are present in minor amounts.

Calcite is the most abundant carbonate mineral ( $\sim 75-98$ vol\%) in the primary rock material; hence variable grain size occur among the different samples. In particular, sample K1 have calcite up to 98 vol\%, which shows a strong textural heterogeneity with grain size range from $0.03-0.4 \mathrm{~mm}$ and median one $\sim 0.132 \mathrm{~mm}$. In the examined thin section, calcite shows a more or less hypiodiomorphic cloudy appearance which is due to abundant of fine-grained interstitial calcite (Fig. 1a, 2a). Sample A2 is constituted by calcite $\sim 85$ vol\% and dolomite $\sim 15 \mathrm{vol} \%$. It holds a relative homogeneous appearance with grain size range from 0.01-0.32 $\mathrm{mm}$ and median one $\sim 0.05 \mathrm{~mm}$ (Fig. 1b, 2b). In a thin section scale, veins of large dolomite crystals occur. Sample T3 is characterized by calcite $\sim 77-80 \mathrm{vol} \%$ and dolomite $\sim 20-23 \mathrm{vol} \%$. Very often, veinlets of almost pure calcite $\left(\mathrm{XMgCO}_{3}=0.01-0.03\right)$, some tens to a few hundreds of micrometers thick, can be found along some grain boundaries. Veins of calcite and dolomite could also be found crosscutting grains of fine-grained matrix calcite (Fig. 1c, 2c). Sample T4 have calcite as the predominant mineral (>98 vol\%). In terms of textures, has the homogeneous appearance of a marble-like rock $(0.64-0.88 \mathrm{~mm}$ in size) with large idiomorphic to hypiodiomorphic calcite crystals Crystal grain boundaries are straight and intersect in a triple point at $120^{\circ}$ (Fig. 1d). Finally, the sample T5 has an heterogeneous shape with calcite ( $\sim 88-90 \mathrm{vol} \%)$, dolomite $(\sim 8-10 \mathrm{vol} \%)$ and albite $(<1-2$ vol\%) and grain range from $0.01-0.24 \mathrm{~mm}$ in size. Secondary calcite veins crosscut the host matrix (Fig. 1e, 2e).

The composition of calcite crystals is almost pure. Rare domains have relatively low $\mathrm{Mg}$ calcite crystals $\left(\mathrm{XMgCO}_{3}=0.01-0.03\right)$. Isometric to anhedral dolomite grains have a composition which is nearly to the pure one $\left(\mathrm{XMgCO}_{3}=0.48\right.$ to 0.50$)$. Representative analyses of Mg-calcite and dolomite are shown in table 3.

The main chemical and mineralogical difference between the studied carbonate rocks is the amount of $\mathrm{CaCO}_{3}$ and $\mathrm{MgCO}_{3}$ (in the form of calcite and dolomite), which in terms of $\mathrm{wt} \% \mathrm{CaO}$ is low in $\mathrm{A} 2$ and $\mathrm{T} 3$ (48.09 and $49.36 \mathrm{wt} \%$ respectively) and higher in $\mathrm{K} 1, \mathrm{~T} 4$ and $\mathrm{T} 5$ (54.11, 54.88 and $52.83 \mathrm{wt} \%$ respectively); in terms of $\mathrm{wt} \% \mathrm{MgO}$ is low in $\mathrm{K} 1$ and $\mathrm{T} 4$ (up to $0.65 \mathrm{wt} \%$ ), slightly higher (1.74 wt \%) in $\mathrm{T} 5$ and much higher in $\mathrm{A} 2$ and $\mathrm{T} 3$ 
(4.35 and $3.26 \mathrm{wt} \%$ respectively). The degree of conversion of carbonates is poor at $900^{\circ} \mathrm{C}$ (during 30 minutes of calcination) and much better at $1050^{\circ} \mathrm{C}$, particularly for samples $\mathrm{T} 3, \mathrm{~T} 4$ and $\mathrm{T} 5$. The results for $1200^{\circ} \mathrm{C}$ show no significant improvement over the $1050^{\circ} \mathrm{C}$ yield. Two of the above-mentioned rocks (sample $\mathrm{K} 1$ and A2) have been already tested on industrial scale by producing quick lime and slaked lime. Following industrial criteria (reactivity test described in a German DIN procedure the RDIN values of a highly reactive quick lime is $>30$ and those for an un-reactive one is $<10$ (European Norm En 12485, 1996). Though, our two industrial-tested samples show totally different RDIN values; in particular K1 have RDIN 35 and A2 RDIN 5.

\subsection{X-ray diffraction and Raman examination}

The X-ray diffraction analyses show that calcite is the major mineral phase, followed by dolomite, while quartz and albite occur in minor amounts. For low-Mg calcite, the relatively broad (104) X-ray diffraction peak (Fig. 3a) shows that two bulk compositions of pure calcite and a $\mathrm{Mg}$-rich calcite dominate, with $\mathrm{XMgCO}_{3}$ values up to 0.03 .

Raman spectroscopy corroborates the presence of single grains of pure calcite, Mg-calcite and pure dolomite in the studied carbonates (Fig. 3b-d). Aragonite is not present.

\subsection{Experimental results}

The process of slaking is studied applying TG and DTA thermal analysis. Particularly the correlation of the studied samples K1 and A2 (Fig. 4) already heated at 900,1050 and $1200^{\circ} \mathrm{C}$ shows a well developed trend with increasing calcination temperature. The samples calcined at $900^{\circ} \mathrm{C}$ possess a high percent of the initial carbonate material (an asymmetric endothermic peak at $\sim 750-840^{\circ} \mathrm{C}$ ) which is due to dolomite (higher percent in sample A2 compared to the sample K1) and calcite presence. The endothermic peak at $\sim 420-480^{\circ} \mathrm{C}$ is attributed to the dissociation of hydroxides, both $\mathrm{Mg}(\mathrm{OH})_{2}$ and $\mathrm{Ca}(\mathrm{OH})_{2}$, and especially the latter one.

The results of hydration experiments with the calcination products are shown in figures 5-7. We constructed bivariate plots of reactivity against $(\mathrm{CaO}+\mathrm{MgO})_{\text {Lime }}$ and $\mathrm{CaO}_{\text {Rock }} / \mathrm{CaO}_{\text {Lime }} / \mathrm{MgO}_{\text {Rock }} / \mathrm{MgO}_{\text {Lime }}=$ $\left(\mathrm{CaO}_{\text {Rock }} \cdot \mathrm{MgO}_{\text {Lime }}\right) /\left(\mathrm{CaO}_{\text {Lime }} \cdot \mathrm{MgO}_{\text {Rock }}\right)($ denoted here as $\mathrm{C} / \mathrm{M})$ in order to check, consistent or not, trends of reactivity with composition of limestone or lime. In figure $5 \mathrm{a}$, we observe a systematic increase of reactivity with increasing $(\mathrm{CaO}+\mathrm{MgO})_{\text {Lime }}$ for all of the calcined samples; however, for a given $(\mathrm{CaO}+\mathrm{MgO})_{\text {Lime }}$ content, the reactivity is higher in the $1050^{\circ} \mathrm{C}$ calcined samples indicating that the optimal reactivity is observed at $1050^{\circ} \mathrm{C}$, perhaps due to hard-burnt phenomena or densification of the quick lime structure at higher temperatures (e.g. Shin et al. 2009). A close inspection of the figure 5b, shows a systematic increase of reactivity with decreasing $\mathrm{C} / \mathrm{M}$ ratio for the samples calcined at 1050 and $1200^{\circ} \mathrm{C}$; in contrast, the samples calcined at $900^{\circ} \mathrm{C}$ show a relative constant reactivity value for decreasing $\mathrm{C} / \mathrm{M}$ ratios. As the total $\mathrm{CaO}$ and $\mathrm{MgO}$ in limestone are constant, the $(\mathrm{MgO} / \mathrm{CaO})_{\text {Lime }}$ ratio plays a key role in reactivity behavior. Moreover, the low constant values for the samples calcined at $900^{\circ} \mathrm{C}$ indicate that either the calcination temperature was rather too low or the calcination time of 30 min was too short to produce enough lime.

Figure 6 (a-e) shows the temperature rise vs. hydration time of quick lime at temperature 900,1050 and $1200^{\circ} \mathrm{C}$ for the studied samples. The limestones calcined at $1050^{\circ} \mathrm{C}$ show the steepest and highest temperature rise; at lower/higher calcination temperature the temperature rise is lower. The temperature rise of the limestones calcined at $1200^{\circ} \mathrm{C}$ was lower than that of the $1050^{\circ} \mathrm{C}$ and also the time required for hydration was longer.

Three of the studied limestones share a common feature with high $\mathrm{MgO}$ content ranging from 2.17-5.53 wt\% (samples A2, T3 and T5). These samples also possess the higher $\mathrm{MgO}$ content during calcination, thus the quick limes formed by this process also have high $\mathrm{MgO}$ content.

\section{Discussion}

Various authors suggest, that following industry conditions (high retention time in the kiln), the lower the calcination temperature, the higher the reactivity value (Commandré et al. 2007). However on a laboratory basis, such as we do, our results indicate an inversion of this correlation at low temperatures. In particular, the samples calcinated at $900^{\circ} \mathrm{C}$ show lower values of reactivity. An increase in calcination temperature (up to $1050^{\circ} \mathrm{C}$ ) results in a change of the reactivity behavior and a maximum for all of the studied samples is reached.

Figure 6 (a-e) shows that quick limes calcined at temperature of $1050^{\circ} \mathrm{C}$ have the highest reactivity. Moreover our sample's porosity values were not well-correlated with the reactivity ones. Experimental results by Shin et al. (2009) show that the quick lime calcined at $1200^{\circ} \mathrm{C}$ is less reactive, probably due to larger grain size (grain growth during calcination) and lower porosity (denser structure). These authors suggested a temperature of $\sim 1100^{\circ} \mathrm{C}$ as the optimum calcination temperature for the highest reactivity values with the largest specific area. Apparently, at this temperature a lot of pores form due to dissociation of carbonates, whereas quick limes 
calcined at lower temperatures $\left(900\right.$ and $\left.1000^{\circ} \mathrm{C}\right)$ tend to have less pores and a lower specific surface area due to incomplete quick lime production and remnants of the original limestone. We support the idea of Shin et al. (2009) which indicates that at calcination temperatures $>1200^{\circ} \mathrm{C}$ the structure of quick lime becomes more dense and compact and the grains recrystallize and tend to become larger, which results in a reduction of the existing pore space. Consequently, the hydration process itself cannot quickly proceed into the interior mass of the quick lime and requires more time to go to completion. This is supported also by thermal analysis results where relatively high content of un-transformed carbonate to lime is still preserved.

The $\mathrm{MgO}$ content plays an important role in reactivity rate of lime due to early decomposition of $\mathrm{MgCO}_{3}$ to $\mathrm{MgO}$, producing hard burnt samples. As we stated above, the higher the amount of $\mathrm{MgO}$, the lower the lime reactivity and maximum the hydration temperature, and the longer the hydration time. In case of non-hard burnt samples, a low concentration of $\mathrm{MgO}$ (lower than 2-3 wt\%) can accelerate the hydration rate of the quick lime (Potgieter et al. 2003). In practice, the $\mathrm{MgO}$ vs. reactivity rate are inversely correlated, and the samples calcined at $1200^{\circ} \mathrm{C}$ share a common, low reactivity rate, with those calcined at $900^{\circ} \mathrm{C}$.

To better visualize the hydration process we compare the amount of $\mathrm{H}_{2} \mathrm{O}$ that reacted with the quick lime against reactivity rate. Reactivity values are divided by the time required to reach Tmax, giving the reactivity rate. Figure 7 shows that at constant values of reactivity rate the water required to complete hydration is lower for samples calcinated at lower temperatures; for example, the quick lime calcined at temperature of $1050^{\circ} \mathrm{C}$ needs much less water for hydration relative to the equivalent samples at $1200^{\circ} \mathrm{C}$. Also, the slope of the curve for the samples calcined at $1200^{\circ} \mathrm{C}$ is steeper compared to the ones for lower calcination temperature.

A possible reaction model

As shown in figure 8 the limestone calcined at low temperature are considered to have a different internal microstructure compared to the samples calcined at 1050 and $1200^{\circ} \mathrm{C}$. Currently, the available data for the samples calcined at low temperature (at $900^{\circ} \mathrm{C}$; Fig. 8) suggest that the calcination process was incomplete, most likely restricted to the grain boundary areas, with relict cores of the original carbonate grains; thus these samples require much less water to be added in order to react all $\mathrm{CaO}$ to $\mathrm{Ca}(\mathrm{OH})_{2}$. As the center of these grains remain as calcium carbonate while the outsides are converted to $\mathrm{Ca}(\mathrm{OH})_{2}$, these samples show poor hydraulic properties with very low reactivity values. At higher calcination temperatures $\left(1050\right.$ and $1200^{\circ} \mathrm{C}$; Fig. 8), the reaction has gone to completion within the 30 minutes furnace time and the entire stone is converted to $\mathrm{CaO}$ (and $\mathrm{MgO}$ ). At higher calcination temperatures two phenomena become important; one is recrystallization and increase of grains size and the other is a reduction of grain boundary area and pore space from 1050 to $1200^{\circ} \mathrm{C}$ (Bhattacharya et al. 2001). Moreover, for the temperature of $1200^{\circ} \mathrm{C}$ probably the heat reaches the core rapidly and the outside layer is overheated forming a hard outer shell called "hard burn" where water cannot penetrate, therefore, the slaking process is greatly retarded or prevented. Due to that, the hydraulic behavior of the samples calcined at $1050^{\circ} \mathrm{C}$ exhibits better values in terms of reactivity, whereas at higher temperatures, the hydration process requires much more time to go to completion.

\section{Conclusions}

Concluding, the correlation of the primary texture character of the carbonate rock is not fully connected with the reactivity values of the resulted quick lime. In particular, the heterogeneous shape as expressed by the sample K1 and the homogeneous one of the sample T4, both correspond to a highly reactive slaked lime. In contrast, previous studies have shown that quick limes produced by calcination of inhomogeneous limestones are more reactive compared to quick-limes produced from more homogeneous and compact limestones (Moropoulou et al. 2001).

So now we are in place to answer in the fundamental question of the present study; if the physico-chemical properties of the carbonate rocks are highly enough to influence the reactivity behavior of the slaked lime. The aforementioned critical analysis of the overall examination of the carbonate rocks reveal the crucial conclusion of a inadequacy factor that should confined in terms of chemical, textural and physical properties of quick/slaked lime.

\section{References}

Bhattacharya, T.K., Ghosh, A. \& Das, S.K. (2001). Densification of reactive lime from limestone. Ceramics International, 27, 455-459

Boynton, W.V. (1980). Chemistry and Technology of Lime and Limestone. (2nd ed.). Wiley, New York, 5 - 33, $132-164$

Commandré, J.-M., Salvador, S. \& Nzihou, A. (2007). Reactivity of laboratory and industrial limes. Trans 
IChemE, Part A, Chemical Engineering Research and Design, 85(A4), 473-480

European Norm En 12485 (1996). Chemicals used for the treatment of water intended for human consumption-Calcium carbonate, high-calcium lime and half-burnt dolomite. Test Methods

Koukis, G. \& Sabatakakis, N. (2002). Technical Geology. (1st Ed.). Papasotiriou, Athens, 516 pp. (in Greek)

Moffat, W. \& Walmsley, M.R.W. (2004). Improving Energy Efficiency of a Lime Kiln. Proceedings of Joint SCENZ/FEANZ/SMNZI Conference, Hamilton, 17-24

Moropoulou, A., Bakolas, A. \& Aggelakopoulou, E. (2001). The effects of limestone characteristics and calcination temperature to the reactivity of the quicklime. Cement and Concrete Research, 31, 633-639

Oates, J.A.H. (1998). Lime and Limestone. Chemistry and Technology, Production and Uses. Wiley - VCH, Weinheim, $9-62,117-250$

Potgieter, J.H. Potgieter, S.S. \& DeWaal, D. (2003). An empirical study of factors influencing lime slaking Part II: lime constituents and water composition. Water SA, 29 (2), 157-160

Rilem, T.C. (1980). Recommendations issued by 13-MR Committee on mortars and renderings. Materials and Structures, 13, 55-66

Schwarzkopf, F. (1994). Lime Burning Technology - a manual for lime plant operators. (3rd ed.). Svedala Industries Kennedy, Van Saun

Shin, H.G., Kim, H., Kim, Y.N. \& Lee, H.S. (2009). Effect of reactivity of quick lime on the properties of hydrated lime sorbent for $\mathrm{SO}_{2}$ removal. Journal of Materials Science Technology, 25, 329-332

Table 1. Whole-rock major element compositions (in wt $\%$ oxides) and mineral modes of the studied carbonate rocks

\begin{tabular}{|l|l|l|l|l|l|}
\hline Sample & \multicolumn{1}{|c|}{$\mathrm{K} 1$} & \multicolumn{1}{c|}{$\mathrm{A} 2$} & \multicolumn{1}{c|}{ T3 } & \multicolumn{1}{c|}{ 4 } & \multicolumn{1}{c|}{ T5 } \\
\hline $\mathrm{SiO}_{2}$ & 0.89 & 1.21 & 1.21 & 0.85 & 0.99 \\
\hline $\mathrm{Al}_{2} \mathrm{O}_{3}$ & 0.38 & 0.58 & 0.56 & 0.33 & 0.35 \\
\hline $\mathrm{FeO}$ & 0.2 & 0.51 & 0.45 & 0.08 & 0.65 \\
\hline $\mathrm{MgO}$ & 0.65 & 4.35 & 3.26 & - & 1.74 \\
\hline $\mathrm{CaO}$ & 54.11 & 48.09 & 49.36 & 54.88 & 52.83 \\
\hline $\mathrm{Na}_{2} \mathrm{O}$ & 0.22 & 0.31 & 0.35 & 0.25 & 0.25 \\
\hline $\mathrm{K}_{2} \mathrm{O}$ & 0.21 & 0.12 & 0.12 & 0.08 & 0.08 \\
\hline $\mathrm{H}_{2} \mathrm{O}$ & 0.27 & 0.43 & 0.38 & 0.23 & 0.4 \\
\hline $\mathrm{CO}_{2}$ & 43.23 & 42.57 & 42.37 & 43.12 & 43.43 \\
\hline Total & 100.17 & 98.16 & 98.06 & 99.82 & 100.72 \\
\hline $\mathrm{Calcite}$ & $95 \%$ & $75 \%$ & $80 \%$ & $98 \%$ & $90 \%$ \\
\hline Dolomite & $3 \%$ & $20 \%$ & $15 \%$ & - & $8 \%$ \\
\hline Albite & $<2 \%$ & $3 \%$ & $<2 \%$ & $<2 \%$ & $<2 \%$ \\
\hline Quartz & - & $<2 \%$ & $<2 \%$ & - & - \\
\hline -: Only in trace amounts. & \\
\hline
\end{tabular}

Table 2. Measurements of specific weight and porosity of the different carbonate rocks

\begin{tabular}{|l|l|l|}
\hline Sample & \multicolumn{1}{|c|}{$\begin{array}{c}\text { Specific weight (in } \\
\mathrm{gr} / \mathrm{cm}^{3} \text { ) }\end{array}$} & Porosity (in \%) \\
\hline K1 & 2.700 & 1.006 \\
\hline A2 & 2.728 & 1.538 \\
\hline T3 & 2.721 & 1.521 \\
\hline T4 & 2.709 & 0.558 \\
\hline T5 & 2.684 & 2.630 \\
\hline
\end{tabular}


Table 3. Representative compositions of low-Mg calcite and dolomite from the studied carbonate rocks

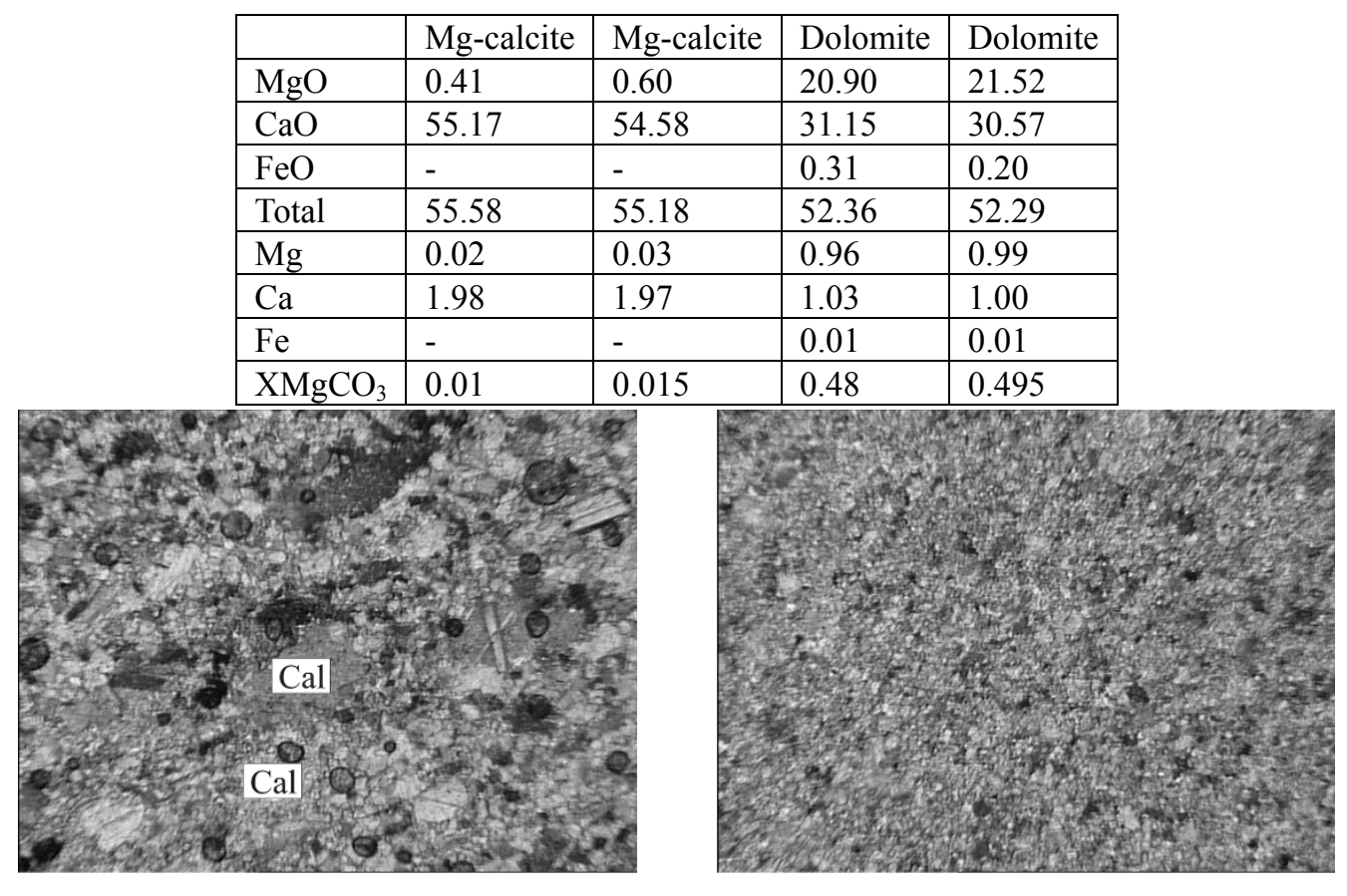
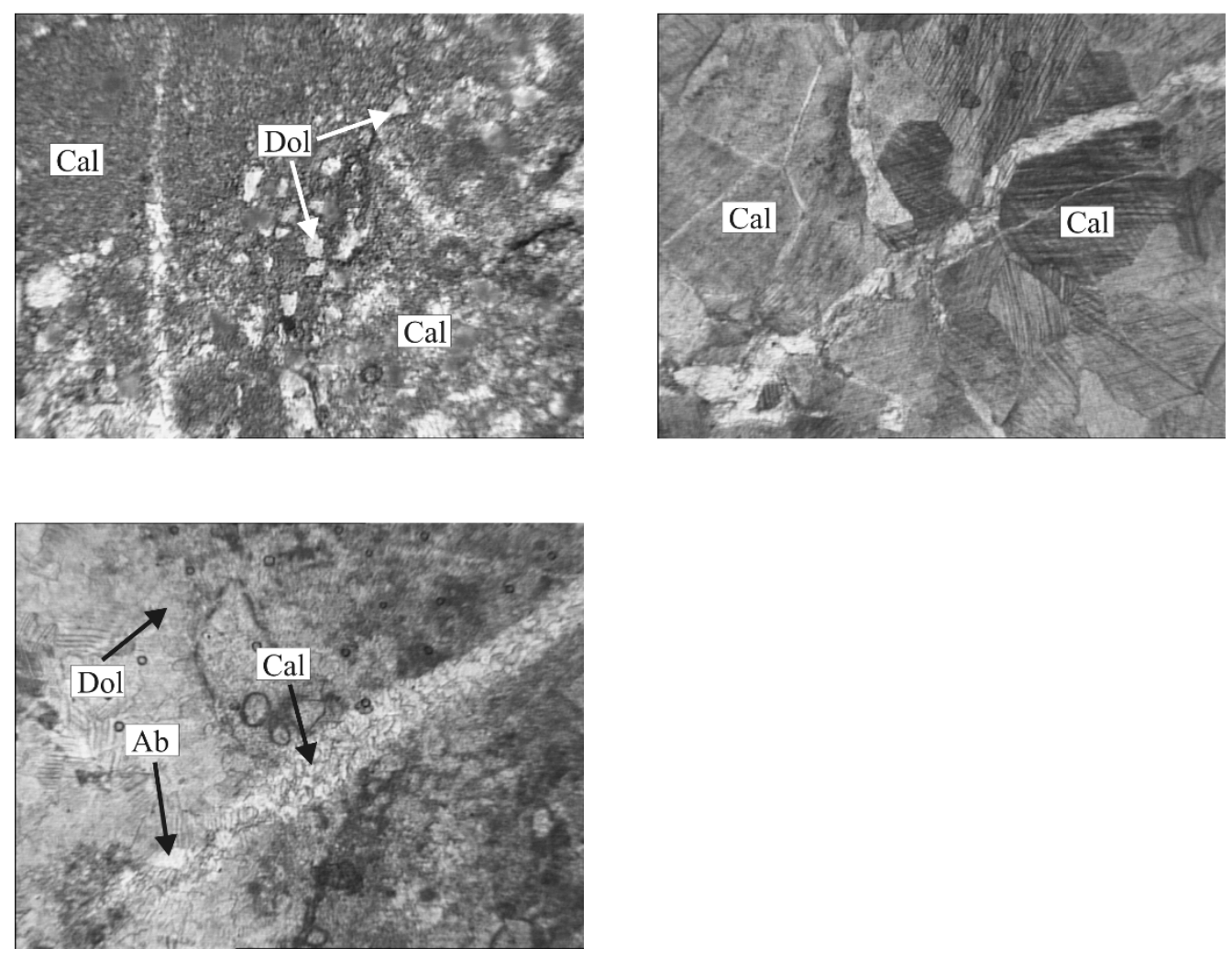

Figure 1. Optical microscopy for (a) hypiodiomorphic cloudy appearance of matrix calcite with abundant fine-grained interstitial calcite grains. (b) Sample A2 shows a relative homogeneous appearance. (c) Veinlets of almost pure calcite, some tens to a few hundreds of micrometers thick, occur along some grain boundaries. (d) Relative homogeneous appearance of a marble-like rock (sample T4) with large idiomorphic to hypiodiomorphic calcite crystals. Crystal grain boundaries are straight and intersect in a triple point at $120^{\circ}$. (e) Sample T5 show an heterogeneous character with secondary calcite veins crosscutting the host matrix 

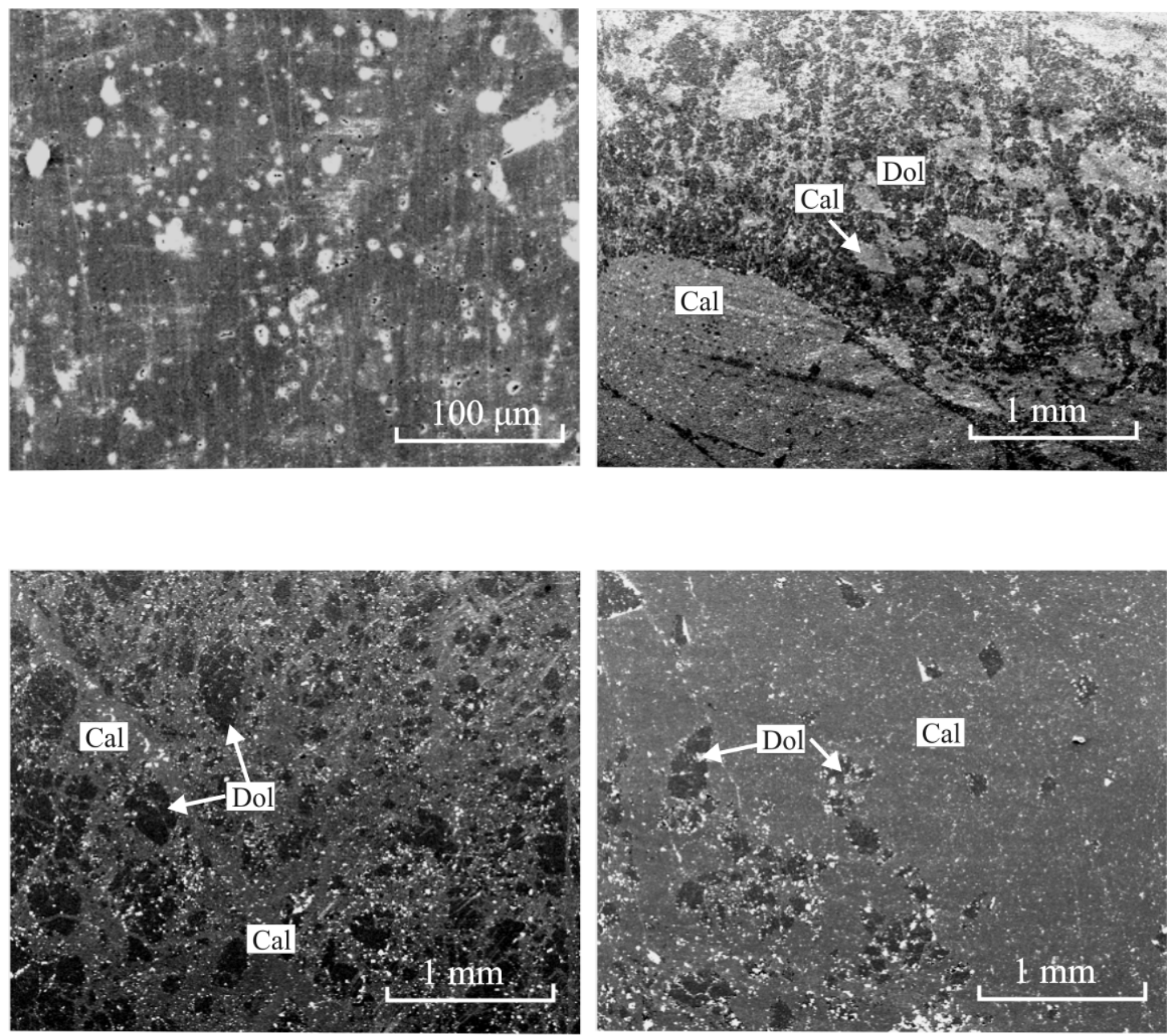

Figure 2. Back Scattered Electron (BSE) images of: (a) sample K1 with calcite as a predominant mineral phase. (b, c, d) Dolomite grains in a calcite host. (b) sample A2, (c) sample T3 and (d) sample T5
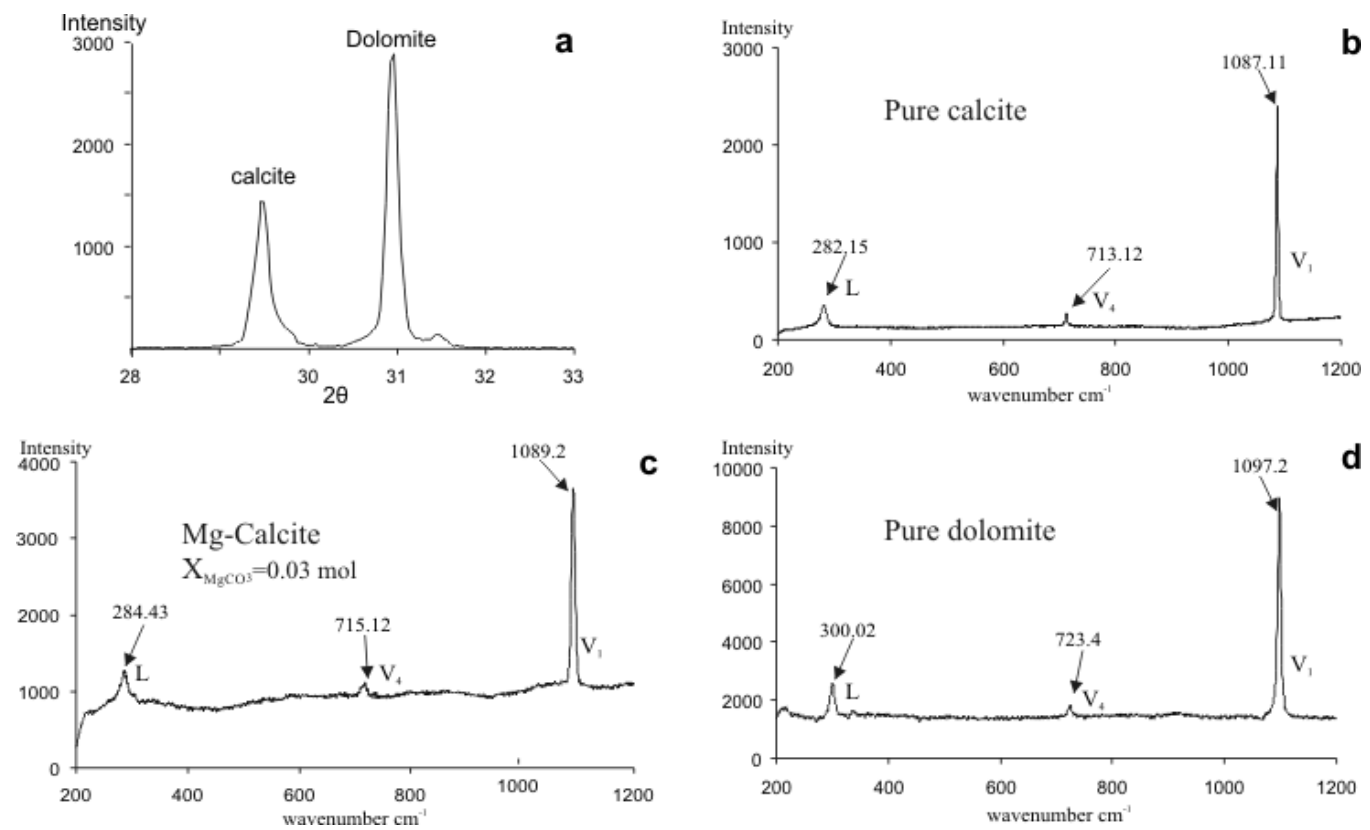

Figure 3. (a) X-ray diffractogram for $2 \theta 28-33^{\circ}$ (CuKa radiation) showing the (104) peaks of calcite and dolomite. (b-d) Micro-Raman spectra of pure calcite, low-Mg calcite $\left(\mathrm{XMgCO}_{3} 0.03 \mathrm{~mol}\right)$ and pure dolomite 


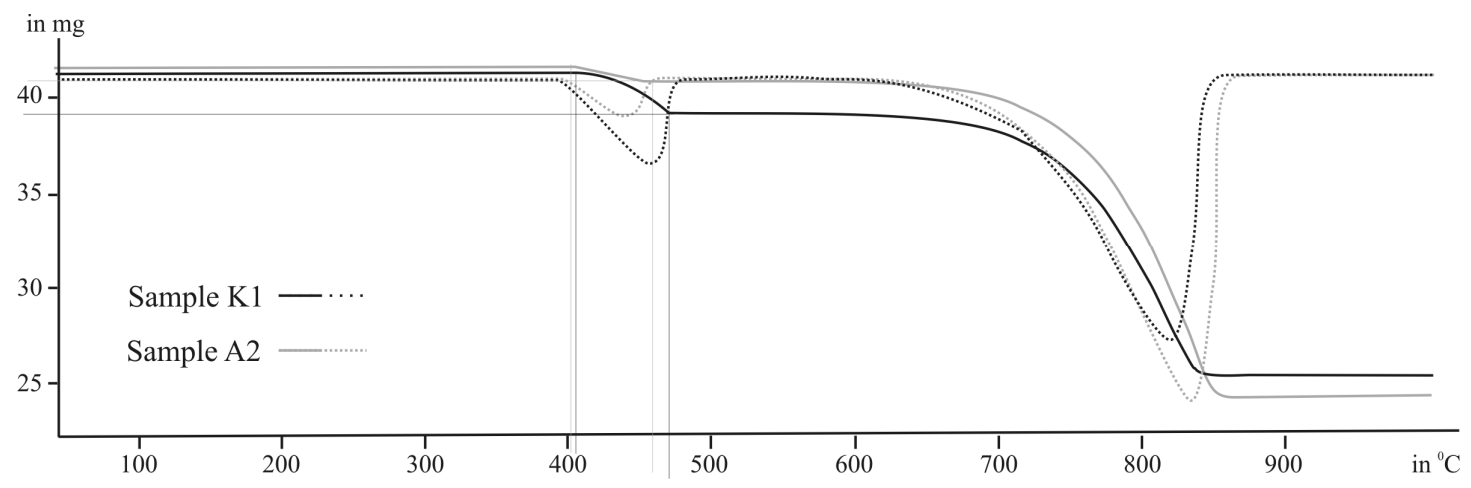

Figure 4. Comparison of TG and DTA thermal analysis results of samples K1 and A2
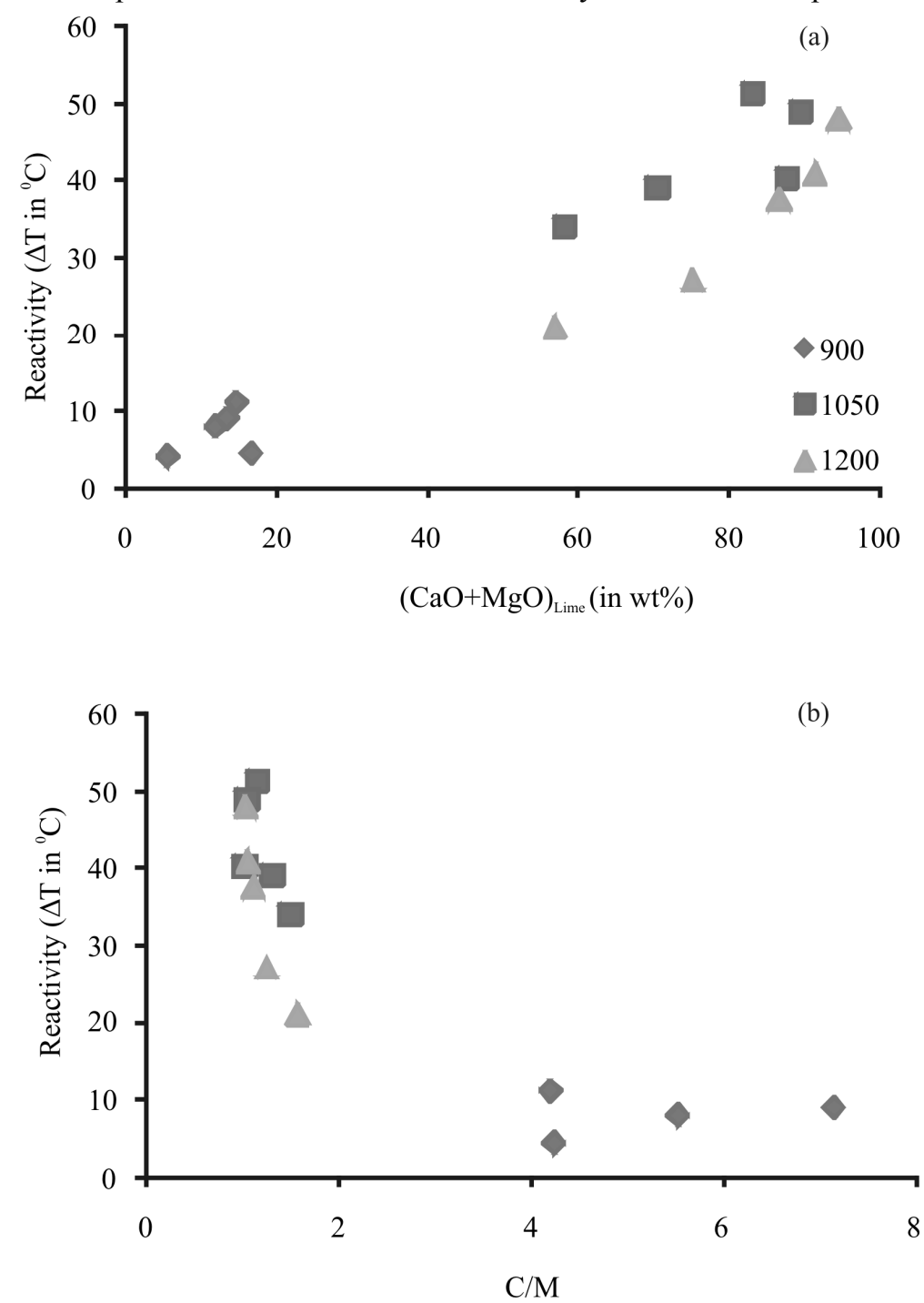

Figure 5. Variations of Reactivity against (a) $(\mathrm{CaO}+\mathrm{MgO})_{\mathrm{Lime}}$ and (b) $\mathrm{C} / \mathrm{M}$ ratio. $\mathrm{C} / \mathrm{M}$ is expressed as $\left(\mathrm{CaO}_{\text {Rock }} \cdot \mathrm{MgO}_{\text {Lime }}\right) /\left(\mathrm{CaO}_{\text {Lime }} \cdot \mathrm{MgO}_{\text {Rock }}\right)$ 

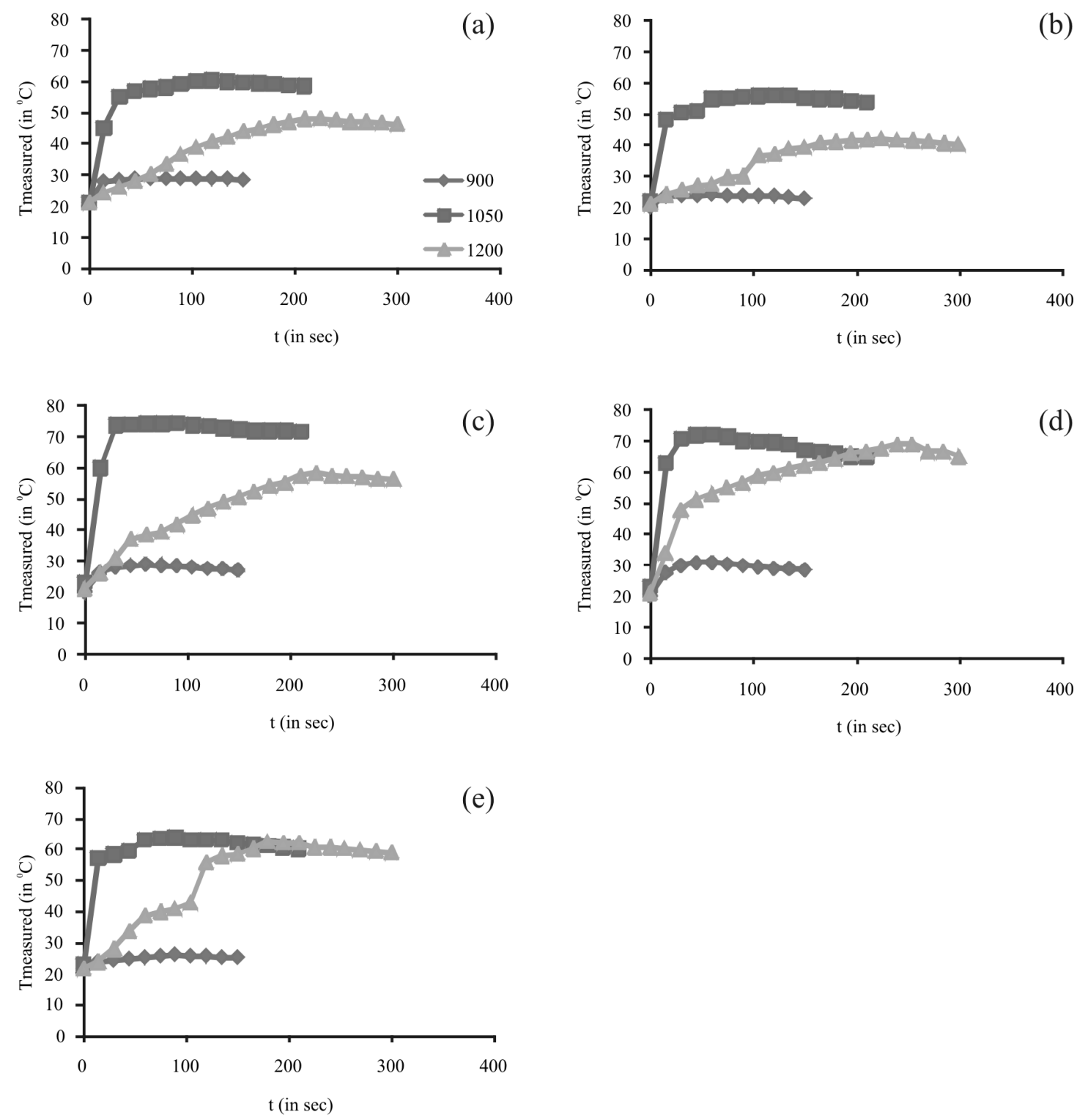

Figure 6. (a-e) $T_{\text {measured }} v$ s time plots showing temperature rise during hydration of quick lime at the three calcination temperatures $\left(900,1050\right.$ and $1200^{\circ} \mathrm{C}$ ). Samples (a) K1, (b) A2, (c) T3, (d) T4 and (e) T5 


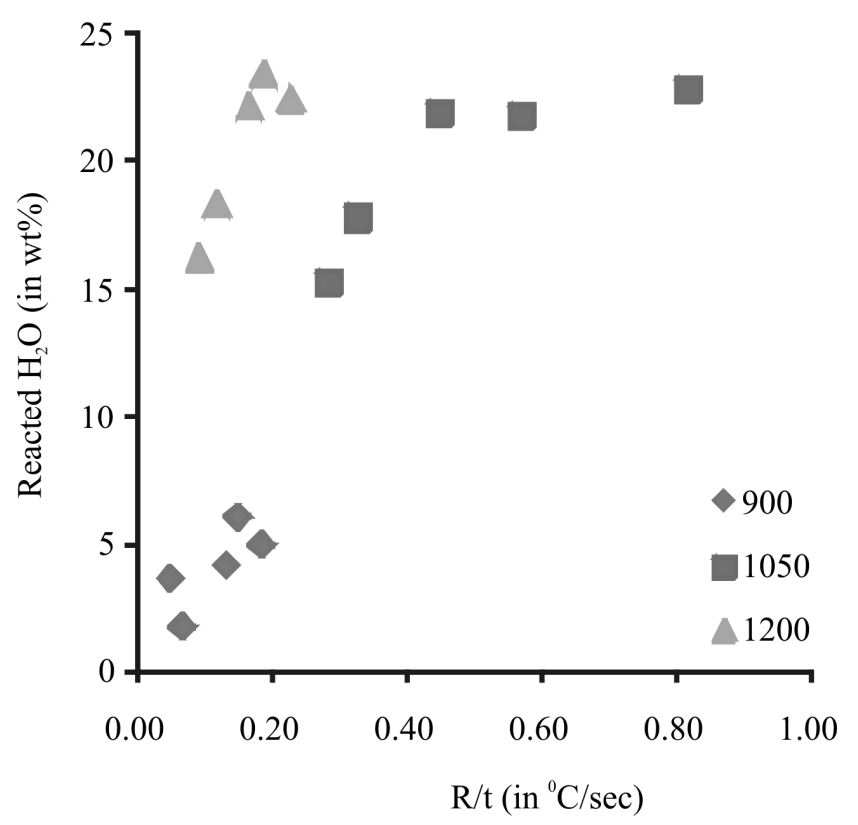

Figure 7. Variation of reactivity rate of quick limes against the $\mathrm{H}_{2} \mathrm{O}$ reacted with the calcined samples at various temperatures

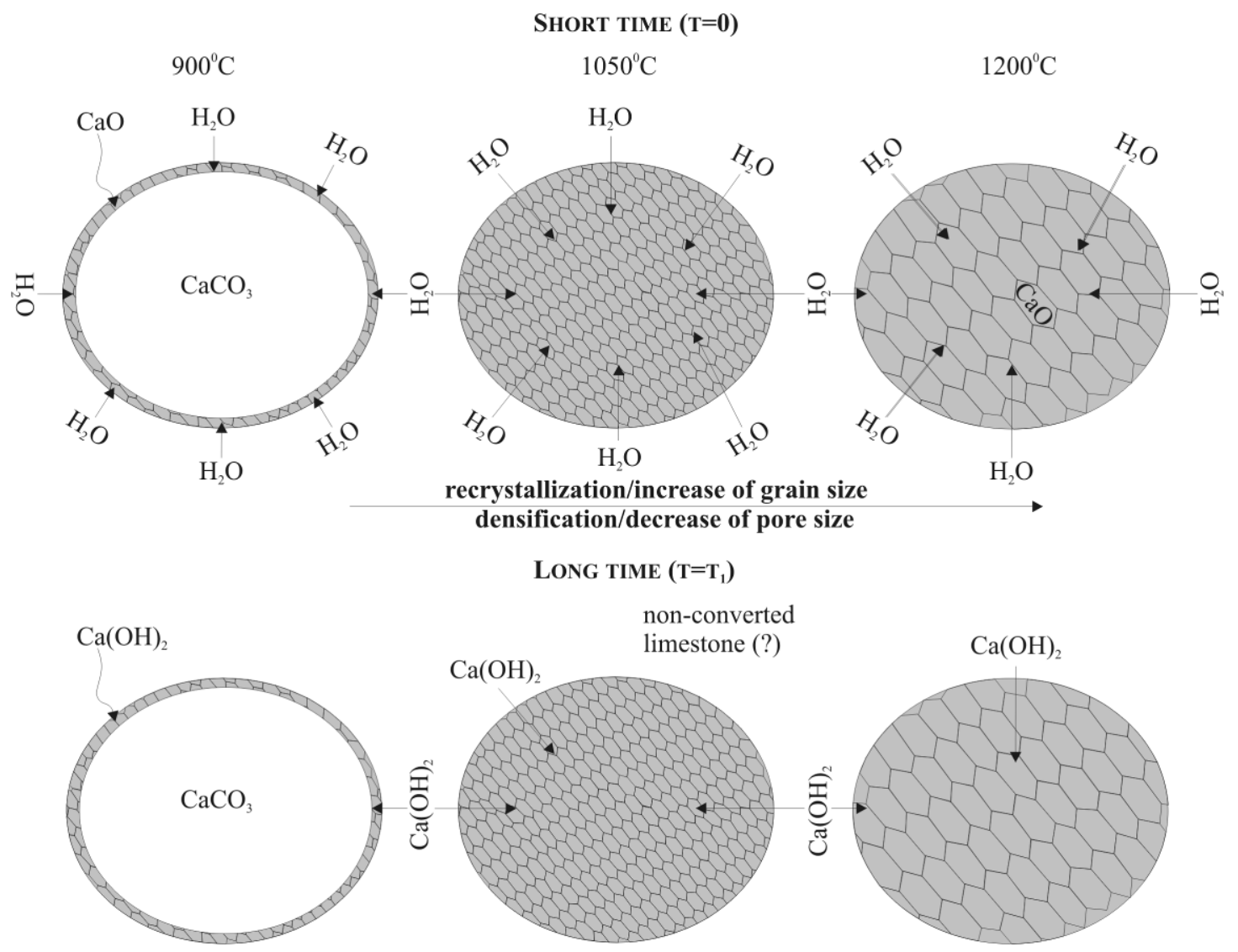

Figure 8. A possible two stage schematic model showing the hydration behavior of quick lime starting from different calcination temperatures 